\title{
ПРОЕКТ ПЕРІОПЕРАЦІЙНОГО ТРИГЕРНОГО ІНСТРУМЕНТУ ЯК МЕХАНІЗМУ РЕТРОСПЕКТИВНОЇ ІДЕНТИФІКАЦІЇ НЕСПРИЯТЛИВИХ ПОДІЙ В АНЕСТЕЗІОЛОГІЧНІЙ ПРАКТИЦІ
}

\author{
${ }^{1}$ ДУ «Український інститут стратегічних досліджень МОЗ України», м. Київ, Україна \\ ²ВДНЗУ «Українська медична стоматологічна академія», м. Полтава, Україна
}

\begin{abstract}
Мета: на основі закордонного прототипу розробити власний, адаптований до вітчизняних умов тригерний механізм ретроспективної ідентифікації несприятливих подій, що вже трапилися з пацієнтами в періопераційний період у минулому.

Матеріали і методи. Як закордонний прототип взято друге видання Глобального тригерного інструменту Американського інституту поліпшення охорони здоров'я.

Результати. Розроблено адаптовану до національних умов та потреб служби анестезіології України анестезіологічно-хірургічну версію, яку представлено у вигляді «Періопераційного тригерного інструменту», що складається з 43 тригерів, стратифрікованих у 4 модулі для ретроспективної ідентифікації різних груп інцидентів.

Висновки. Представлений у роботі варіант Глобального тригерного інструменту $є$ інноваційним для України механізмом ретроспективної ідентифікації інцидентів із безпекою пацієнтів, що може стати прообразом подібних ініціатив у інших медичних спеціальностях.
\end{abstract}

КЛЮЧОВІ СЛОВА: безпека пацієнта; анестезіологія; несприятлива подія; ідентифікація; глобальний тригерний інструмент.

В арсеналі систем охорони здоров'я на сьогодні $€$ десятки методів та інструментів ідентисрікації проблем із безпекою пацієнтів [1, 3, 6], але жоден із них не виявився універсальним детектором $[4,5]$. 3'ясувалося, що уявлення про стан проблеми безпеки пацієнтів у конкретному лікувальному закладі залежить від методу отримання інформації [9].

До недавнього минулого команди клініцистів та адміністраторів намагалися ідентифікувати медичні помилки та несприятливі події в основному через системи добровільного і примусового інцидент-звітування, що $€$ інструментами безпекового моніторингу поточної, теперішньої діяльності, але з'ясувалося, що такі системи дозволяють виявити не більше 10-20\% інцидентів, причому 90 \% з них не пов'язані з завданням пацієнту жодної шкоди [7]. Виникла потреба у розробці більш ефективних методів ідентисрікації проблемних зон у сорері безпеки пацієнтів, у тому числі розкриття фрактів медичних помилок та несприятливих подій, що вже трапились у минулому (аналіз безпекових аспектів минулої діяльності). Одним із рішень виявився так званий тригерний механізм - інструмент, що ідентифрікує несприятливі події шляхом регулярних цілеспрямованих ретроспективних аудитів невеликих вибірок медичної документації.

Термін «тригерний інструмент» вперше з'явився у медичному лексиконі на початку 90 -х років у
США при описанні нового методу детекції потенційних несприятливих подій, пов'язаних із ліками. Американський інститут поліпшення охорони здоров'я (the Institute for Healthcare Improvement IHI) вдосконалив цей метод і розробив так званий глобальний тригерний інструмент, що дозволив проводити кількісну оцінку небажаних явищ у загальному масштабі системи охорони здоров'я, використовуючи простий і відтворювальний процес [8]. Цей інструмент був успішно адаптований для використання у Великій Британії та інших країнах світу і виявився особливо ефективним у таких клінічних галузях, як педіатрія та акушерство. Найбільш широкого розповсюдження він набув на вторинному, стаціонарному, рівні надання медичної допомоги, хоча існують і версії, адаптовані для використання на рівні первинної, амбулаторної ланки.

Робота присвячена вирішенню завдання створення проекту такого тригерного інструменту для служби анестезіології України та є фрагментом НДР ДУ «Український інститут стратегічних досліджень МОЗ України» «Науковий супровід, моніторинг та оцінка моделей розвитку ссрери охорони здоров'я в Україні на регіональному рівні» (№ держ. реєстрації 0115U002852).

Мета дослідження: на основі закордонного прототипу розробити власний, адаптований до вітчизняних умов тригерний механізм ретро-

\footnotetext{
(с) Р.М. Федосюк, О.М. Ковальова, 2018
} 
спективної ідентифікації несприятливих подій, що вже трапилися 3 пацієнтами в періопераційний період у минулому.

Матеріали і методи. Як закордонний прототип для розробки проекту власного тригерного інструменту ідентифрікації минулих періопераційних несприятливих подій, як одного з ретроспективних механізмів ідентифікації інцидентів із безпекою пацієнтів в анестезіологічній практиці, обрано друге видання Глобального тригерного інструменту Американського інституту поліпшення охорони здоров'я [8].

Результати дослідження та їх обговорення. На основі обраного прототипу розроблено анестезіологічно-хірургічну його версію, адаптовану до реалій вітчизняної системи охорони здоров'я і потреб вітчизняної служби анестезіології. Запропонована нами версія, яку ми назвали «Періопераційний тригерний інструмент», містить 43 тригери, згруповані у 4 модулі - Модуль лікування і догляду, або лІД-модуль (15 тригерів), Модуль медикаментозної терапії, або МТ-модуль (13 тригерів), Модуль операції та анестезії, або ОТА-модуль (11 тригерів), та Модуль інтенсивної терапії, або IT-модуль (4 тригери).

Модуль-1. Лікування і догляд (15 тригерів)

ЛІД-1 - трансфузія крові або їі продуктів. Будь-яке переливання еритроцитарної маси або цільної крові у періопераційний період повинно досліджуватись 3 точки зору причинно-наслідкового зв'язку. Переливання під час операції та впродовж перших 24 год після операції декількох одиниць крові або об'ємів крові, що перевищили очікувану крововтрату, найімовірніше, пов'язане 3 періопераційною несприятливою подією. Випадки, коли надмірна крововтрата сталася до операції, несприятливими подіями, зазвичай, не вважаються. Пацієнти, у яких потреба у переливанні свіжозамороженої плазми або тромбоцитів виникла на тлі антикоагулянтної терапії, швидше за все, зазнали побічної дії цих препаратів.

лІД-2 - клінічна смерть або зупинка дихання. Усі випадки зупинки серця та дихання повинні ретельно розслідуватись, оскільки вони можуть бути кульмінацією несприятливої події. Проте деякі з них можуть бути пов'язані з прогресуванням захворювання. Так, зупинка серця інтраопераційно або у перші 24 год після операції 3 високою вірогідністю є несприятливою подією. Навпаки, раптова серцева аритмія, що призвела до зупинки серця, не є несприятливою подією.

ЛІД-3 - гострий гемодіаліз. Потреба у гострому діалізі може бути як закономірним наслідком прогресування захворювання, так і несприятливою подією. Прикладом несприятливої події $€$ ниркова недостатність як побічна реакція на введення контрасту для радіологічних досліджень.

ЛІД-4 - позитивний результат культури крові. Позитивний результат бактеріологічного дослідження крові у будь-який момент періоду госпіталізації є несприятливою подією, що асоціюється $з$ нозокоміальними іноекціями, і потребує розслідування.

ЛІД-5 - тромбоз глибоких вен (ТГВ) або тромбоемболія легеневої артерії (ТЕЛА) за результатами рентгенологічного або ультразвукового дослідження. Розвиток ТГВ або ТЕЛА в період перебування у лікарні в більшості випадків $€$ несприятливою подією. Рідкісні винятки можуть бути закономірним наслідком захворювань, таких як рак або порушення згортання крові. Проте у більшості пацієнтів розвиток ТГВ або ТЕЛА вважається завданням пацієнту шкоди, пов'язаної 3 медичною допомогою, навіть якщо вживали всі необхідні запобіжні заходи. Якщо госпіталізацію проводили з приводу вже діагностованих ТГВ або ТЕЛА, ситуацію оцінюють на предмет можливого причинно-наслідкового зв'язку з попереднім епізодом медичної допомоги, наприклад, з недавно перенесеним хірургічним втручанням.

ЛІД-6 - зниження рівня гемоглобіну або гематокриту на $25 \%$ або більше від вихідного. Будьяке зниження рівня лабораторних показників гемоглобіну або гематокриту (на 25 \% та більше від вихідного) необхідно досліджувати, особливо якщо таке зниження відбулось упродовж відносно короткого періоду часу, наприклад, 72 год або менше. Даним тригером, зазвичай, ідентифрікуються кровотечі, що можуть бути пов'язані 3 використанням антикоагулянтів чи аспірину або розвитком хірургічного ускладнення. Зниження гемоглобіну або гематокриту само по собі не $€$ несприятливою подією, якщо воно не пов'язане 3 наданням медичної допомоги.

ЛІД-7 - падіння пацієнта. Падіння пацієнта у лікувальному закладі завжди $€$ дефектом медичної допомоги і може бути результатом впливу ліків, збоїв у роботі обладнання або дефіцитом навченого персоналу. Будь-яке падіння в установі, що спричиняє травму, незалежно від причини, $\epsilon$ несприятливою подією; падіння без шкоди не $є$ несприятливою подією. Падіння, що є результатом лікування (наприклад, впливу медикаментів), потрібно вважати несприятливою подією, навіть якщо падіння виникає поза лікарнею.

ЛІД-8 - пролежні. Пролежні є несприятливими подіями, якщо вони виникли в період госпіталізації.

ЛІД-9 - повторна госпіталізація пацієнта впродовж 30 днів після виписування 3 лікарні. Будь-яка повторна госпіталізація, особливо в межах 30 днів після виписування, може бути наслідком своєчасно не ідентифікованої несприятливої події. Така подія може не проявлятися відразу після виписування пацієнта з лікарні, особливо якщо тривалість перебування була мінімальною. Прикладами несприятливих подій, що зумовлюють повторну госпіталізацію, $€$ інфекції післяопераційних ран, ТГВ та ТЕЛА. 
ЛІД-10 - примусова фрізична іммобілізація (фріксація) пацієнта. При будь-якій фріксації пацієнтів слід переглядати задокументовані причини таких обмежень та оцінювати їх на предмет можливого зв'язку з побічною дією медикаментів.

ЛІД-11 - інфекції, пов'язані з наданням медичної допомоги. Будь-яка інфекція, що розвивається після госпіталізації в лікарню, найбільш ймовірно, є несприятливою подією.

ЛІД-12 - внутрішньолікарняний інсульт. Гостре порушення мозкового кровообігу може бути пов'язане з виконанням деяких медичних процедур (наприклад, хірургічного втручання, дефібриляції передсердь) або призначенням антикоагулянтів. Якщо інсульт виник після проведення такої процедури, він вважається несприятливою подією.

ЛІД-13 - переведення пацієнта у відділення або заклад більш високого рівня допомоги. Усі переведення пацієнтів на вищий рівень у межах закладу або в інший заклад повинні ретельно аналізуватись, оскільки вони можуть бути наслідком несприятливих подій, що призвели до погіршення клінічного стану пацієнтів. Так, переведення пацієнта до відділення інтенсивної терапії з причини порушення дихання та інтубації трахеї, що стали наслідком природного прогресування чи інфекційного загострення хронічного обструктивного захворювання легень (ХОЗЛ), не вважається несприятливою подією; в той час як переведення 3 причини порушення дихання, спровокованого надмірною седацією пацієнта з ХОЗЛ або спричиненого ТЕЛА, що розвинулась після операції, $€$ несприятливою подією.

ЛІД-14 - ускладнення будь-якої процедури. Ускладнення, спричинені будь-якою процедурою, $€$ несприятливою подією.

ЛІД-15 - інші. Під тригером «ЛІД-15» реєструють будь-які ідентифріковані в процесі рецензування історій хвороб інциденти з безпекою пацієнтів, що відповідають визначенню несприятливої події, але не пов'язані з жодним іншим із вищенаведених тригерів модуля «Лікування і догляд».

Модуль-2. Медикаментозна терапія (13 тригерів).

MT-1 - позитивний результат дослідження випорожнення на токсини Clostridium difficile. Позитивний результат даного аналізу вважається несприятливою подією, якщо існує анамнез призначення пацієнту антибіотиків.

MT-2 - подовження АЧТЧ (активованого часткового тромбопластинового часу) до >100 с. Контрольоване подовження АЧТЧ (у 2-3 рази) є терапевтичною метою у пацієнтів, які отримують гепарин із приводу тромбозів. Само по собі подовження АЧТЧ не є несприятливою подією. Аби 3'ясувати, чи мала місце несприятлива подія у випадках надмірного його подовження, потрібно шукати такі прояви геморагічного синдрому, як синці, гематоми, кровотечі, зниження рівнів гематокриту та гемоглобіну.

MT-3 - збільшення МНС (міжнародного нормалізованого співвідношення) до >6. Підвищення зазначеного показника само по собі також не $\epsilon$ несприятливою подією. Подібно до випадків подовження АЧТЧ, щоб визначити, чи мала місце несприятлива подія при МHC>6, потрібно аналізувати наявні в історії хвороби дані на предмет кровотеч та інших геморагічних ускладнень.

MT-4 - зниження рівня глюкози до <2,75 ммоль/л. У випадку наявності у пацієнта клінічних проявів гіпоглікемії таке зниження вважається несприятливою подію і вимагає аналізу схеми інсулінотерапії та режиму харчування пацієнта.

MT-5 - підвищення показників залишкового азоту або креатиніну сироватки удвічі порівняно з базовим рівнем. Потрібно проаналізувати історію хвороби на предмет можливого призначення або некоректного дозування нефротоксичних препаратів, що спричиняють токсичне ураження нирок. Проте підвищення зазначених показників у пацієнтів із цукровим діабетом часто свідчить про прогресування захворювання, а не про несприятливу подію.

MT-6 - призначення вітаміну К у зв'язку з високUм МНС. Потрібно проаналізувати наявні дані на предмет діагностики кровотеч, виявлення крові у випорожненні, появи надмірних синяків чи великих гематом, розвитку геморагічного інсульту, зниження показників гематокриту чи гемоглобіну, котрі є прикладами несприятливих подій, зумовлених коагулопатією.

MT-7 - застосування антигістамінних препаратів (супрастину, тавегілу, дифенгідраміну та ін.). Антигістамінні препарати часто застосовуються при алергічних реакціях на лікарські засоби. Якщо такі препарати вводились, необхідно переглянути записи на предмет зв'язку їх призначення з фрактами алергічних реакцій на медикаменти або продукти крові, що є несприятливими подіями.

MT-8 - застосування фрлумазенілу. Флумазеніл $€$ антидотом препаратів бензодіазепінової групи (седуксен, мідазолам), тому фракт його призначення потрібно оцінювати з точки зору можливого передозування седативних із зазначеної групи. Прикладами несприятливих подій у випадках передозування бензодіазепінів є тяжка гіпотензія та виражена, надто тривала седація.

MT-9 - застосування налоксону. Налоксон $€$ потужним антагоністом наркотичних анальгетиків. Його призначення 3 високою вірогідністю може свідчити про передозування наркотичних засобів, що є несприятливою подією. Не вважаються несприятливими подіями випадки зловживання наркотиками та їх передозування самими пацієнтами. 
MT-10 - застосування протиблювотних засобів. Нудота та блювота часто $є$ побічним ефектом застосування деяких препаратів у пацієнтів як хірургічного, так і нехірургічного профрілів. Нудота та блювота, що перешкоджають харчуванню і післяопераційному відновленню або призводять до затримки фрізіологічних виділень, є подіями, котрі необхідно віднести до розряду несприятливих. На противагу, один чи два епізоди, успішно проліковані протиблювотними препаратами, не вважаються несприятливими подіями.

MT-11 - надмірна седація/діпотензія. Потрібно проаналізувати медичну документацію на предмет можливих асоціацій між введенням седативних і анальгетичних препаратів та розвитком млявості й артеріальної гіпотензії. Перегляньте записи лікаря, медсестер, суміжних спеціалістів та консультантів для підтвердження чи спростування підозри на передозування.

MT-12 - раптова відміна препарату. Різка необґрунтована відмова від подальшого використання препарату - це тригер, що потребує подальшого дослідження для з'ясування причини такої події. Термін «Раптова відміна» визначається як несподівана відмова від подальшого лікування препаратом або відхилення від типової практики його призначення. Проте припинення, наприклад, введення внутрішньовенного антибіотика для переходу на пероральне лікування, зрозуміло, не є несприятливою подією.

MT-13 - інше. Цей тригер використовується для реєстрації несприятливих медикаментозних подій, що виявляються в процесі рецензування, але не пов'язані з жодним іншим із вищеперелічених тригерів модуля «Медикаментозна терапія».

Модуль-3. Операція та анестезія (11 тригерів).

ОТА-1 - повторна операція. Повернення пацієнта до операційної кімнати може бути запланованим заздалегідь або незапланованим, і обидва випадки можуть бути несприятливою подією. Прикладом несприятливої події, що спонукає до «запланованої» ре-операції, $€$ санаційна релапаротомія при запущеному гнійно-септичному процесі у черевній порожнині внаслідок несвоєчасного розпізнання захворювання чи запізнілого першого втручання. Прикладом несприятливої події, що спонукає до незапланованого повернення пацієнта до операційної, $€$ внутрішня кровотеча, котра виникла після попередньої операції і потребувала повторної операції для встановлення джерела кровотечі та її усунення. Навіть якщо повторна операція стає експлоративною (пошуковою), тобто не виявляє десекту медичної допомоги, вона вважається несприятливою подією.

ОТА-2 - зміна початкового плану оперативного втручання. Коли порядок виконання оперативного втручання, зазначений у післяопераційних записах, відрізняється від запланованого, потрібно шукати причини такої зміни. Непередбачена зміна плану проведення процедури внаслідок розвитку ускладнень або збою у роботі пристрою чи обладнання повинна розглядатися як несприятлива подія, особливо якщо вона призвела до збільшення тривалості терміну госпіталізації або нанесення пацієнту шкоди.

ОТА-3 - госпіталізація пацієнта у відділення інтенсивної терапії після операції. Така госпіталізація може бути плановою і позаплановою. Остання часто пов'язана 3 виникненням небажаного інциденту під час операції та анестезії. Так, після операцій 3 приводу аневризми аорти пацієнтів завжди госпіталізовують до відділень інтенсивної терапії, в той час як після ендопротезування колінного суглоба - тільки у випадках розвитку ускладнень. Рецензент повинен визначити істинну причину госпіталізації пацієнта у відділення інтенсивної терапії.

ОTA-4 - інтубація, повторна інтубація або застосування неінвазивної вентиляції легень (ВіРAP) у післяопераційній палаті. Анестезія, седативні засоби та анальгетики можуть призвести до депресії дихання, що вимагає інтубації раніше не інтубованого пацієнта, ре-інтубації уже дезінтубованого пацієнта або застосування у пацієнта допоміжної вентиляції і є прикладом несприятливої події внаслідок медикаментозної помилки.

ОТА-5 - проведення позапланового рентгенологічного дослідження зони операції інтраопераційно або в ранній післяопераційний період. Факт проведення рентгенівського дослідження у зв'язку з підозрою на випадкове залишення під час операції стороннього предмета в рані чи порожнині тіла пацієнта або у зв'язку з сумнівними результатами підрахунку кількості предметів (інструментів, серветок, кульок, губок), що використовувались під час операції, $є$ позитивним тригером. Проведення додаткового втручання 3 приводу виявлення такого предмета $€$ несприятливою подією. Своєчасна ідентифікація і видалення стороннього післяопераційного тіла без проведення повторної операції або завдання пацієнту будь-якої іншої додаткової шкоди несприятливою подією не вважається.

ОТА-6 - інтра- або післяопераційна смерть пацієнта. Усі випадки смертей на операційному столі слід вважати несприятливими подіями.

ОТА-7 - штучна вентиляція легень (ШВЛ) упродовж >24 год після операції. Потреба у механічній вентиляції легень довше 24 післяопераційних годин може бути свідченням несприятливої інтраопераційної або післяопераційної події. У пацієнтів із фоновим легеневим або м'язовим захворюванням складність зі швидким відлученням від вентилятора після операції може бути закономірною, але наявність зазначеної обставини не повинна автоматично виключати можливість 
несприятливої події. Рецензенти повинні використовувати клінічне судження для визначення того, чи було інтра- та післяопераційне використання ШВЛ промахом персоналу чи закономірним перебігом захворювання.

ОТА-8 - інтраопераційне застосування адреналіну, норадреналіну, налоксону. Зазначені препарати рутинно під час операції не призначаються. Гіпотензія, спричинена кровотечею, або надмірна седація чи анальгезія, спричинена передозуванням препаратів, є прикладами несприятливих подій, при яких можуть призначатись вказані медикаменти.

ОТА-9 - післяопераційне підвищення рівня тропоніну-І до >1,5 нг/мл. Зазначена лабораторна знахідка може вказувати на несприятливу подію, що асоціюється $з$ періопераційною ішемією міокарда.

ОТА-10 - травма, відновлення або видалення органа під час оперативного втручання. Видалення або відновлення органа може бути запланованою частиною оперативного втручання і не $€$ несприятливою подією. Проте видалення або відновлення органа внаслідок невдалого хірургічного втручання або випадкової травми є несприятливою подією.

ОТА-11 - будь-яке ускладнення операції. Дана рубрика використовується для реєстрації будьякого ускладнення анестезії та операції, що не підпадає під інші, вищенаведені тригери модуля «Операція та анестезія».

Модуль-4. Інтенсивна терапія (4 тригери).

IT-1 - вперше діагностована пневмонія. Будьяка пневмонія, вперше діагностована у відділенні інтенсивної терапії, повинна ретельно аналізуватись. Якщо наявні дані свідчать про початок пневмонії ще до госпіталізації у стаціонар, вона не вважається несприятливою подією, але якщо вона виникла у лікарні, її відносять до групи несприятливих подій.

IT-2 - повторна госпіталізація у відділення інтенсивної терапії. Будь-яка повторна госпіталізація у відділення інтенсивної терапії повинна аналізуватись 3 точки зору ідентифрікації несприятливої події, що до цього призвела.

IT-3 - виконання будь-якої процедури у відділенні інтенсивної терапії. Виконання будь-якої специфрічної процедури у відділенні інтенсивної терапії вимагає дослідження. Проаналізуйте усі процедури та маніпуляції, що були виконані пацієнту. Оскільки ускладнення не завжди фріксуються у медичній документації, за особливостями догляду та лікування можна іноді розпізнати несприятливу подію, що стоїть за показаннями до виконання втручання.

IT-4 - інтубація/реінтубація трахеї. Будьяка незапланована інтубація та повторна інтубація у відділенні інтенсивної терапії повинні розглядатись з точки зору ідентифрікації несприятливої події, що до цього спонукала.

Тригерний інструмент допомагає командам рецензентів швидко аналізувати невеликі вибірки медичної документації на предмет ретроспективної ідентифікації позитивних тригерів серед тих, що були заздалегідь обрані з загального переліку для аналізу. Методологія глобального тригерного інструменту рекомендує щомісяця аналізувати 20 історій хвороб. Мультидисциплінарна команда або два рецензенти випадковим чином формують невелику вибірку історій хвороб. Рецензентам рекомендується встановити 20-хвилинний термін на «сканування» однієї історії хвороби. Рецензент при цьому повинен вивчати історію хвороби лише на предмет наявності тригера, що є ключем до можливої несприятливої події, а не читати її з першої до останньої сторінки. Досвідчені рецензенти рекомендують у першу чергу аналізувати такі розділи медичної карти стаціонарного хворого, як повний діагноз та його ускладнення, виписний епікриз, листок призначень, результати лабораторних досліджень, перелік та описання проведених процедур і втручань, записи консультантів, листок моніторингу, що ведуться середнім медичним персоналом. Виявлення позитивного тригера вимагає подальшого пошуку для ідентифрікації або виключення потенційно асоційованої з ним несприятливої події. Усі ідентифріковані через тригерний механізм несприятливі події стратифрікуються за типом і тяжкістю та аналізуються на предмет їх кореневих причин. У подальшому розробляються та впроваджуються заходи 3 їх попередження у майбутньому. Для всіх прорецензованих історій хвороб реєструється тривалість перебування пацієнтів у лікарні, включно день госпіталізації та день виписування. Це дозволяє розрахувати прийняті у світі показники кількості несприятливих подій на 1000 пацієнтднів або на 100 пацієнтів. Кінцевою метою такої роботи $є$ елімінація причин несприятливих подій та відстеження змін у часовій перспективі для демонстрації ефективності вжитих заходів.

\section{Висновки}

Представлений у роботі варіант адаптованого до потреб вітчизняної служби анестезіології глобального тригерного інструменту $є$ інноваційним для України механізмом ретроспективної ідентифікації інцидентів із безпекою пацієнтів. Оскільки в системі охорони здоров'я України жодних механізмів інцидент-моніторингу, за виключенням ініційованої МОЗ системи повідомлень про випадки побічних реакцій або відсутності ефеективності лікарських засобів [2], не впроваджено, розроблений нами для служби анестезіології «Періопераційний тригерний інструмент» може стати прообразом подібних ініціатив у інших медичних спеціальностях. 
Перспективи подальших досліджень полягають в обґрунтуванні, розробленні та впровадженні нових механізмів і технологій розпізнавання та менеджменту інцидентів із безпекою пацієнтів в анестезіологічній практиці та розширенні за їх рахунок інструментальної бази системи безпеки пацієнтів у службі анестезіології України.

\title{
Список літератури
}

1. Ковальова О. М. Методи детекції інцидентів з безпекою пацієнтів у медичній практиці / О. М. Ковальова, Р. М. Федосюк // Безпека пацієнтів в Україні: стан і шляхи їі покращення : матеріали Міжнар. наук.-практ. конф., 6-7 червня 2017 р. - Дніпро, 2017. - С. 63-65.

2. Про затвердження Порядку здійснення нагляду за побічними реакціями лікарських засобів, дозволених до медичного застосування : наказ МОЗ України від 27.12.2006 р. № 898.

3. Федосюк Р. Н. Основные методы детекции инцидентов с безопасностью пациентов в медицине / Р. Н. Федосюк, Е. М. Ковалева, В. И. Похилько // Современная стоматология. - 2018. - № 1 (70). - С. 38-42.

4. A comparison of hospital adverse events identified by three widely used detection methods / J. M. Naessens, C. R. Campbell, J. M. Huddleston [et al.] // Int. J. Qual Health Care. - 2009. - Vol. 21 (4). - P. 301-307.

5. Comparison of methods for detecting medication errors in 36 hospitals and skilled-nursing facilities / E. A. Flynn, K. N. Barker, G. A. Pepper [et al.] // Am. J. Health Syst. Pharm. - 2002. - Vol. 59 (5). - P. 436-446.

6. Detecting adverse events for patient safety research: a review of current methodologies / H. J. Murff, V. L. Patel, G. Hripcsak [et al.] // Journal of Biomedical Informatics. - Vol. 36, Issues 1-2. - 2003. - P. 131-143.

7. Evidence Scan: Global Trigger Tool. The Health Foundation. - 2010. - 22 p. Electronic resource. Mode access: https:// www.health.org.uk/sites/health/files/EvidenceScanGlobalTriggerTools.pdf

8. Griffin F. A. IHI Global Trigger Tool for Measuring Adverse Events (Second Edition). IHI Innovation Series white paper I F. A. Griffin, R. K. Resar. - Cambridge, Massachusetts: Institute for Healthcare Improvement, 2009. - 43 p. Electronic resource. Mode access: http://app.ihi.org/webex/gtt/ihiglobaltriggertoolwhitepaper2009.pdf

9. Shojania K. G. The elephant of patient safety: what you see depends on how you look / K. G. Shojania // Jt. Comm. J. Qual. Patient Saf. - 2010. - Vol. 36. - P. 399-401.

\begin{abstract}
References
1. Kovaliova, O.M., \& Fedosiuk, R.M. (2017). Metody detektsii intsydentiv z bezpekoiu patsiientiv u medychnii praktytsi [Methods of detection of incidents with patients' safety in medical practice]. Bezpeka patsiientiv $v$ Ukraini: stan i shliakhy yii pokrashchennia: materialy mizhnar. nauk.-prakt. konferentsii - Safety of Patients in Ukraine: State and Ways of its Improvement: International Materials. science-practice Conf., Dnipro, June 6-7, (pp. 63-65) [in Ukrainian].

2. Nakaz MOZ Ukrainy vid 27.12.2006 r № 898 "Pro zatverdzhennia Poriadku zdiisnennia nahliadu za pobichnymy reaktsiiamy likarskykh zasobiv, dozvolenykh do medychnoho zastosuvannia" [Order of the Ministry of Health of Ukraine dated December 27, 2006, No. 898 "On Approval of the Procedure for Supervision of Side Effects of Medicinal Products Permitted for Medical Use"] [in Ukrainian].
\end{abstract}

3. Fedosyuk, R.N., Kovaleva, E.M., \& Pokhilko V.I. (2018). Osnovnyye metody detektsii intsidentov s bezopasnostyu patsiyentov $\mathrm{v}$ meditsine [The main methods of detecting incidents with the safety of patients in medicine]. Sovremennaya stomatologiya - Modern Dentistry, 1 (70), 38-42 [in Russian].

4. Naessens, J.M., Campbell, C.R., \& Huddleston J.M. (2009). A comparison of hospital adverse events identified by three widely used detection methods. Int. J. Qual. Health Care, 21 (4), 301-307.

5. Flynn, E.A., Barker, K.N., \& Pepper G.A. (2002). Comparison of methods for detecting medication errors in 36 hospitals and skilled-nursing facilities. Am. J. Health Syst. Pharm., 59 (5), 436-446.

6. Murff, H.J., Patel, V.L., \& Hripcsak G. (2003). Detecting adverse events for patient safety research: a review of current methodologies. Journal of Biomedical Informatics, 36, Issues 1-2, 131-143.

7. Evidence Scan: Global Trigger Tool. The Health Foundation (2010), (n.d.). - Retrieved from: https://www.health.org.uk/ sites/health/files/EvidenceScanGlobalTriggerTools.pdf

8. Griffin, F.A., \& Resar, R.K. (2009). IHI Global Trigger Tool for Measuring Adverse Events (Second Edition). IHI Innovation Series white paper. Cambridge, Massachusetts: Institute for Healthcare Improvement. - Retrived from: http://app.ihi.org/ webex/gtt/ihiglobaltriggertoolwhitepaper2009.pdf

9. Shojania, K.G. (2010). The elephant of patient safety: what you see depends on how you look. Jt. Comm. J. Qual Patient Saf., 36, 399-401.

\section{ПРОЕКТ ПЕРИОПЕРАЦИОННОГО ТРИГГЕРНОГО ИНСТРУМЕНТА КАК МЕХАНИЗМА РЕТРО- СПЕКТИВНОЙ ИДЕНТИФИКАЦИИ НЕБЛАГОПРИЯТНЫХ СОБЫТИЙ В АНЕСТЕЗИОЛОГИЧЕСКОЙ ПРАКТИКЕ}

Р.Н.Федосюк ${ }^{1}$ Е.М. Ковалёва ${ }^{2}$

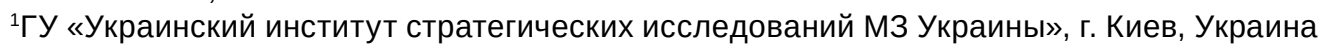

ВГУЗУ «Украинская медицинская стоматологическая академия», г. Полтава, Украина

Цель: на основе зарубежного прототипа разработать собственный, адаптированный к отечественным условиям триггерный механизм ретроспективной идентификации неблагоприятных событий, которые уже произошли с пациентами в периоперационный период в прошлом. 
Материалы и методы. В качестве зарубежного прототипа взято второе издание Глобального триггерного инструмента Американского института улучшения здравоохранения.

Результаты. Разработана адаптированная к национальным условиям и потребностям службы анестезиологии Украины анестезиологически-хирургическая версия, которая представлена в виде «Периоперационного триггерного инструмента», состоящего из 43 триггеров, стратисрицированных в 4 модуля для ретроспективной идентисикации различных групп инцидентов.

Выводы. Представленный в работе вариант Глобального триггерного инструмента является инновационным для Украины механизмом ретроспективной идентификации инцидентов с безопасностью пациентов, который может стать прообразом подобных инициатив в других медицинских специальностях.

КЛЮЧЕВЫЕ СЛОВА: безопасность пациента; анестезиология; неблагоприятное событие; идентификация; глобальный триггерный инструмент.

\section{PROJECT OF A PERIOPERATIVE TRIGGER TOOL AS A MECHANISM FOR THE RETROSPECTIVE IDENTIFICATION OF ADVERSE EVENTS IN ANESTHETIC PRACTICE}

R.M. Fedosiuk' ${ }^{1}$, O.M.Kovalova ${ }^{2}$

${ }^{1}$ Ukrainian Institute of Strategic Studies of the Ministry of Health of Ukraine, Kyiv, Ukraine

${ }^{2}$ Ukrainian Medical Stomatological Academy, Poltava, Ukraine

Purpose: on the basis of a foreign prototype, to develop our own, adapted to domestic conditions, trigger mechanism for retrospective identification of adverse events that already happened to patients in the perioperative period in the past.

Materials and Methods. The second edition of the Global Trigger Instrument of the USA's Institute for Healthcare Improvement $(\mathrm{IHI})$ has been taken as a foreign prototype.

Results. The anesthetic-surgical version adapted to the national conditions as well as the needs of the anesthesiology service of Ukraine and presented in the form of the «Perioperative trigger tool» consisting of 43 triggers stratified into 4 modules for the retrospective identification of various groups of incidents has been developed.

Conclusions. The version of the Global Trigger Instrument presented in the work is an innovative for Ukraine mechanism of the retrospective identification of patient safety incidents that may become a prototype for similar initiatives in other medical specialties.

KEY WORDS: patient's safety; anesthesiology; adverse event; identification; global trigger tool.

Рукопис надійшов до редакції 22.03.2018 p.

Відомості про авторів:

Федосюк Роман Миколайович - завідувач відділення анестезіології та інтенсивної терапії Київської міської клінічної лікарні № 3; тел.: +38(050) 413-64-03.

Ковальова Олена Михайлівна - доктор медичних наук, професор кафедри педіатрії №1 3 пропедевтикою та неонатологією Української медичної стоматолгічної академії; тел.: +38(532) 67-62-98. 